\title{
Antral mucosal diaphragm as a misdiagnosed cause of gastric outlet obstruction: case report and review of the literature
}

\author{
Diafragma mucoso antral como um diagnóstico de obstrução gástrica: \\ relato de caso e revisão da literatura
}

\begin{abstract}
Marcela Del Carlo Bernardi ${ }^{1}$, Ernesto Sasaki Imakuma ${ }^{2}$, Anna Carolina Bastista Dantas ${ }^{3}$, Alyne Korukian Freiberg', Fabio Pinatel Lopasso ${ }^{3}$, Bruno Zilberstein ${ }^{3}$, Ivan Cecconello ${ }^{3}$
\end{abstract}

Bernardi MDC, Imakuma ES, Dantas ACB, Freiberg AK, Lopasso FP, Zilberstein B, Cecconello I. Antral mucosal diaphragm as a misdiagnosed cause of gastric outlet obstruction: case report and review of the literature / Diafragma mucoso antral como um diagnóstico de obstrução gástrica: relato de caso e revisão da literatura. Rev Med (São Paulo). 2015 jan.-mar.;94(1):15-20.

ABSTRACT: The antral web is a thin septum with an aperture varying from 2 to $30 \mathrm{~mm}$ usually discovered in middle or late life because of associated gastric outlet obstruction or peptic ulcer. It is commonly mistaken for a pyloric obstruction. Since surgical excision of the antral diaphragm can cure patient's symptoms, a correct diagnosis is important for not delaying treatment. However, the diagnosis is difficult even after adequate investigation with barium upper gastrointestinal $\mathrm{x}$-ray series or endoscopy. Therefore, the present study seek to notify this pathology as a possible cause of gastric outlet obstruction providing an illustrative case report and review the pertinent literature. Case Report: A 56 years old man presented complaint of pyrosis, epigastric fullness after eating and loss of weight for over three years. His past clinical history revealed a perforated peptic ulcer surgery three years ago. Investigation was initially performed with barium upper gastrointestinal $\mathrm{x}$-ray which suggested pyloric stenosis secondary to the previous surgery. Gastric endoscopy identified a mucous tunnel formation with a $10 \mathrm{~mm}$ diameter aperture in the pre-pyloric region. The patient was also submitted to a computerized tomography (CT) of the abdomen and pelvis for surgical planning for correction of pyloric stenosis and demonstrated an apparently thickening of the gastric wall and reduction of the diameter of the antropyloric region. The patient was then submitted to lapartomy with resection of the antral web. After 6 months, the patient is asymptomatic.

KEYWORDS: Antral web; Antral diaphragm; Surgery; Gastric surgery; Gastric outlet obstruction.
RESUMO: O diafragma antral é um fino septo com uma abertura variando de 2 a $30 \mathrm{~mm}$ usualmente diagnosticado na meia idade ou depois, associado à obstrução da via de saída do estômago ou à ulcera péptica. É frequentemente confundido com obstrução pilórica. Como a excisão cirúrgica do diafragma antral pode curar os sintomas do paciente, o diagnóstico correto é importante para não atrasar o tratamento. Contudo, o diagnostico permanence dificuldado, mesmo depois de uma investigação adequada com estudo de raio $\mathrm{X}$ contrastado de esôfago-estômago-duodeno (EED) ou endoscopia. Portanto, este estudo procura alertar sobre essa patologia como um possível causa de obstrução da via de saída do estômago através de um relato de caso e de uma adequada revisão de literatura. Relato de caso: Paciente do sexo masculino, 56 anos, com queixa de pirose, plenitude epigástrica após refeições e perda de peso nos últimos três anos. Com história clínica relevante de cirurgia de úlcera gástrica perfurada há três anos. A investigação iniciou com raio X contrastado de EED sugerindo estenose pilórica secundária à cirurgia prévia. A endoscopia gástrica identificou uma formação de mucosa em túnel com abertura de $10 \mathrm{~mm}$ de diâmetro em região pré pilórica. O paciente também foi submetido à tomografia computadorizada de abdome e pelve para planejamento de cirurgia de correção de estenose pilórica, sendo evidenciado um aparente espessamento da parede gástrica e redução do diâmetro da região pré pilórica. Então, o paciente foi submetido a uma laparotomia com ressecção do diafragma antral. Depois de seis meses, o paciente apresentou-se assintomático.

DESCRITORES: Diafragma antral; Cirurgia, Cirurgia gástrica, Obstrução da via gástrica

$1^{\circ}$ lugar Prêmio Oswaldo Cruz - Área Relato de Caso no $33^{\circ}$ COMU - Congresso Médico Universitário da FMUSP, SP, 31 de out. a 02 de nov. de 2014.

Hospital das Clínicas - University of São Paulo Medical School. Financial Source: none. Interest conflict: none.

1. Undergraduate, University of São Paulo Medical School. Email: madelcb@gmail.com, alyne.freiberg@gmail.com.

2. Departament of Surgery, University of São Paulo Medical School, Brazil. Email: eimakuma@gmail.com.

3. Departament of Gastroenterology, University of São Paulo Medical School, Brazil. E-mails: carolbatista.med@gmail.com, fabio lopasso@uol.com.br, brunozib@uol.com.br, icecconello@hotmail.com

Corresponding author: Marcela Del Carlo Bernardi. Address: Dr. Brasilio Machado, 421 - apt. 111. São Paulo SP, Brazil. ZIP: 01230010. E-mail:madelcb@gmail.com. 


\section{INTRODUCTION}

$\mathrm{T}$ The occurrence of gastric antral diaphragm or gastric antral web in an adult patient was first described in 1949 by Sames ${ }^{1}$. The antral web is a thin septum, usually 2 to $4 \mathrm{~mm}$ thick and located 1 to $7 \mathrm{~cm}$ from the pylorus with size of the aperture varying from 2 to $30 \mathrm{~mm}^{2,3,4}$. Age diagnosis ranges from 28 to 84 years with male: female ratio $1: 1.36^{3,4}$. It is usually discovered in middle or late life because of associated gastric outlet obstruction or peptic ulcer ${ }^{2-5}$. The cause of late onset of clinical manifestations is unknown and there is no consensus of etiology in the literature whether antral web is congenital or acquired when diagnosed in adults ${ }^{3-7}$.

This disease is infrequently reported in adults and it is often misdiagnosed. Antral diaphragm is rare and, to date, up to 100 adult patients with this entity were reported ${ }^{2,4,5,8-11}$. It is commonly mistaken for a pyloric obstruction, and differential diagnosis are mucosal prolapse into the pylorus and hipertrophy of the pyloric mucosa $a^{4,12,13}$. Since surgical excision of the antral diaphragm can cure patient's symptoms, a correct diagnosis is important for not delaying treatment. However, the diagnosis is difficult even after adequate investigation with barium upper gastrointestinal $\mathrm{x}$-ray series or endoscopy ${ }^{3}$. Diagnosis during laparotomy and inspection of the resected stomach is possible and is facilitated if the lesion is suspected previously on preoperative investigation through gastroscopic or roentgenologic examination ${ }^{2,3}$. Therefore, the present study seek to notify this pathology as a possible cause of gastric outlet obstruction providing an illustrative case report in which the antral diaphragm was misdiagnosed for a pylorus stenosis after perforated peptic ulcer surgery, describe diagnostic features to make easier the recognition of this entity and review pertinent data of clinical presentation, pathologic features and treatment modalities.

\section{CASE REPORT}

White, 56 years old man, was admitted at our hospital Digestive System's Surgery Service ambulatory. He had complaint of pyrosis, epigastric fullness after eating and loss of weight for over three years. He had been taking up omeprazol for over three years. He was an ex-smoker with 35 year-pack and was not an alcoholic. In physical examination, it was noticed augmented gastric sounds and pain at epigastrium palpation. Abdomen was plain and an umbilical hernia with ring less than $1 \mathrm{~cm}$ that was asymptomatic was found. His past clinical history revealed a perforated peptic ulcer surgery three years ago. He have had those complaints after soon after surgery was performed and symptoms were present intermittently ever since. Surgery was performed at another hospital and only a gastrostomy with suture of the perforation was made.

Investigation was initially performed with barium upper gastrointestinal x-ray (Figure 1). It revealed a slowed barium emptying and a deformity of the antropyloric region. The radiologists suggested that the deformity could be secondary to the previous surgery. Afterwards, gastric endoscopy was performed and identified the presence of a deformity of the antrum by healing process with a mucous tunnel formation with $4 \mathrm{~cm}$ of extension and 10 $\mathrm{mm}$ diameter aperture in the pre-pyloric region (Figure 2). It wasn't possible to pass the endoscopic device through the aperture. No peptic ulcers or signs of gastritis was seen. It was also diagnosed Los Angeles class B oesophagitis at this exam. The patient was also submitted to a computerized tomography (CT) of the abdomen and pelvis for surgical planning for, at this point, the patient had already the misleading diagnosis of pyloric stenosis. (Figure 3 ) This exam demonstrated the web as an apparently thickening of the gastric wall and reduction of the diameter of the antropyloric region.

The patient was then submitted to laparotomy and gastrostomy. The place where the peptic ulcer perforated was easily identified. Old sutures on the stomach could be sensed by palpation at the body of the stomach on the greater curvature, far from the antrum. A thin mucosal tunnel was identified and its aperture was sectioned (Figure 4). An urethral catheter was passed through the opened aperture. When aspirated, bilious content was observed. At this moment, it was clear that the stricture was not caused by the late surgery of this patient. The mucosal tunnel was then identified as an antral web and was completely resected. Suture was performed on the gastric mucosa. Following surgery, patients symptoms diminished and he was dismissed from hospital in the $4^{\text {th }} \mathrm{PO}$ day. After 6 months, the patient is asymptomatic and still in use of omeprazol.

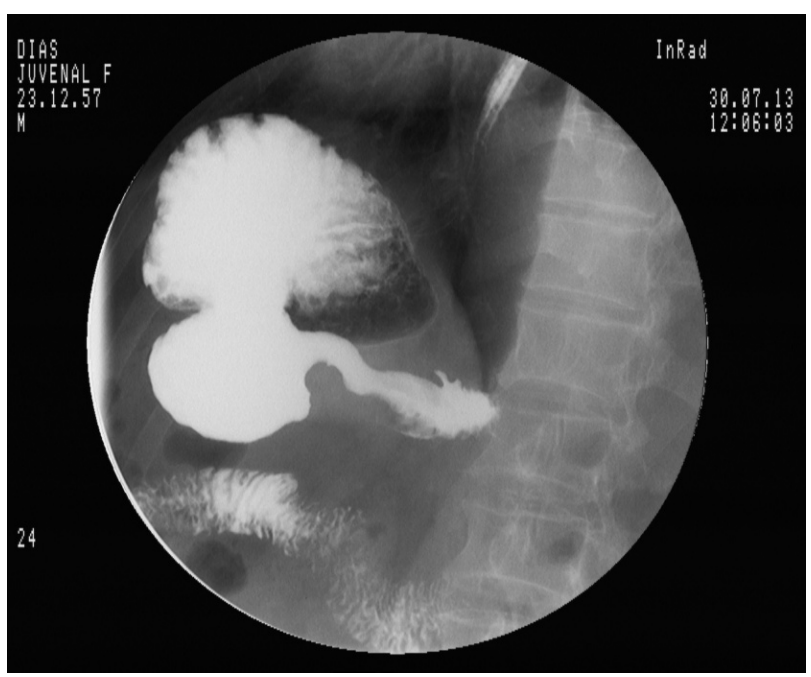

Figure 1. Case report's barium upper gastrointestinal $\mathrm{x}$-ray. The characteristic "double-bulb effect" can be seen and it was interpreted as only a deformity secondary to the previous perforated peptic ulcer surgery 


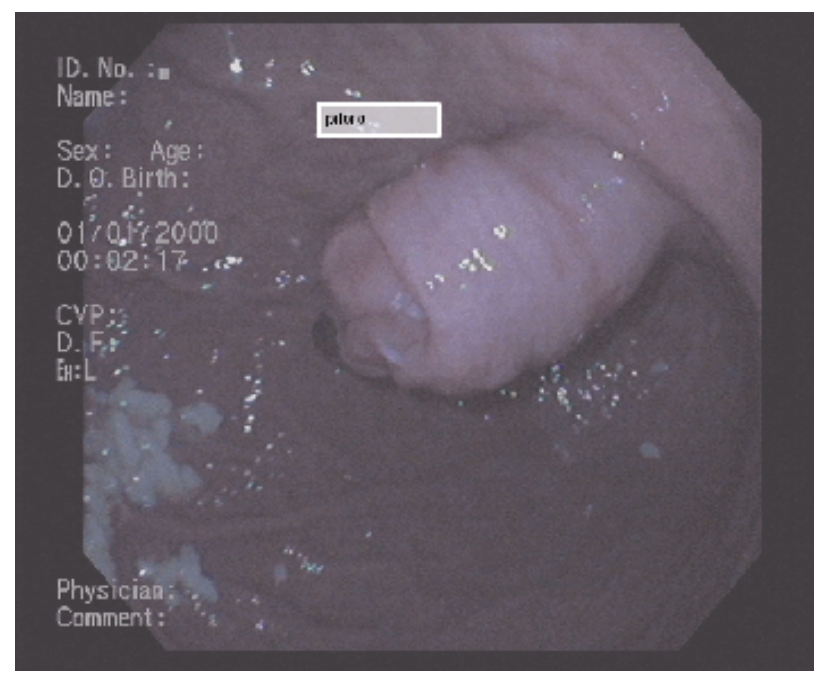

Figure 2. Gastric endoscopy revealing the presence of a deformity of the antrum. The endoscopists interpreted it as a mucous tunnel formation secondary to an ulcer's healing process. Actually, it was a antral web with $4 \mathrm{~cm}$ of extension and $10 \mathrm{~mm}$ diameter aperture

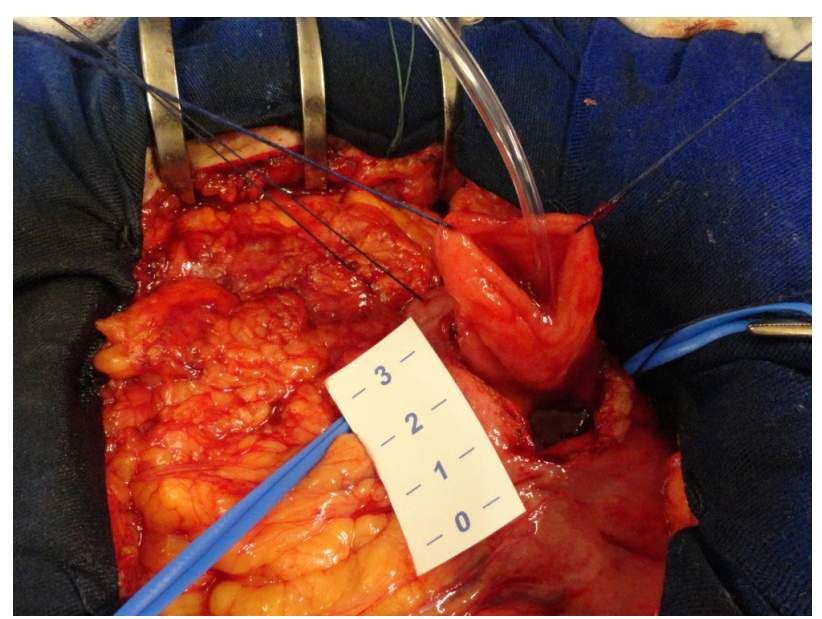

Figure 4. Patient was submitted to laparotomy and gastrostomy. Head is at the upper side of the figure and the feet is at the lowest. The stomach is repaired with a blue vessel-loop at the antropyloric region. The antral diaphragm is repaired with cotton thread and appears as a thin mucosal tunnel. The aperture is sectioned and an urethral catheter is passing thorough up to the duodenum

\section{DISCUSSION}

Near $50 \%$ of patients with confirmed antral web by upper gastrointestinal contrast study are asymptomatic ${ }^{7}$. In adults, clinical presentation usually appears after the fifth decade and include vomiting usually after eating and aggravated by large meals or solid foods, loss of weight, anorexia, severe pyrosis and epigastric fullness after eating. Some patients are able to paliate their symptoms by eating only liquid diet $t^{3,5}$. Pain, not being characterized as pyrosis, is not a usual symptom ${ }^{5}$. The present reported case demonstrated most of the typical symptoms but antral diaphragm was not suspected, being mistaken for pyloric stenosis as the cause of obstruction as the patient

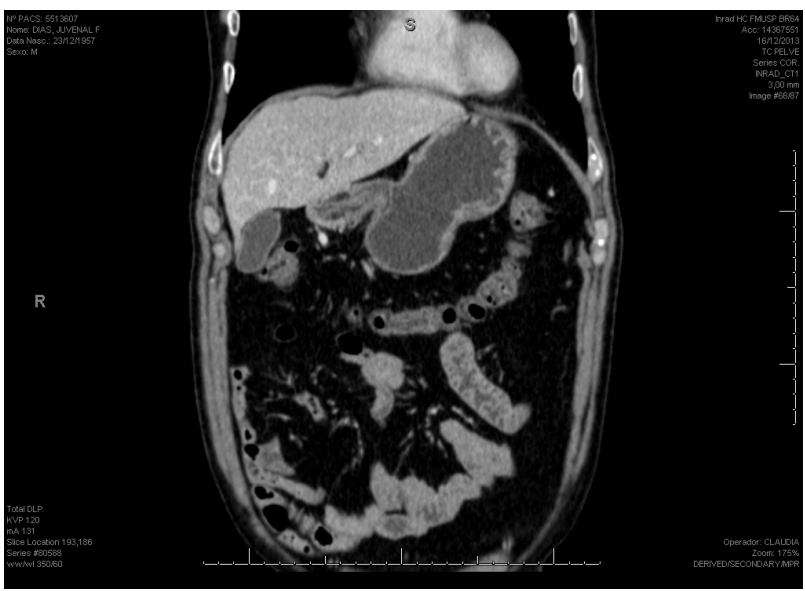

Figure 3. A. Coronal view of computerized tomography (CT) of the abdomen and pelvis. An apparently thickening of the gastric wall can be noticed, causing reduction of diameter of the antropyloric region

had in its past history a surgery for peptic ulcer. Associate abnormalities such as hiatal hernia, gastritis or peptic ulcers contribute or may be responsible for clinical manifestations $s^{2,3,5}$. The present case report suffered from gastric reflux and Los Angeles class B oesophagitis was identified, thus there is the possibility that the symptoms presented by the patient to be secondary to oesophagus reflux and not from the antral web.

The radiologic features of antral web are very relevant. The majority of the first reported cases of antral diaphragm were in radiologic journals ${ }^{14}$. Diagnosis can be made with barium upper gastrointestinal $\mathrm{x}$-ray series and the findings are a "double-bulb effect" and the antral web itself, described as a knifelike band across the antrum $^{5,14,15}$. Air contrast study following administration of an anticholinergic agent to enhance delineation of the diaphragm ${ }^{5}$. Ultrasound has also been suggested as a diagnosis method ${ }^{16}$. Chew et al. ${ }^{16}$ proposed four ultrasound diagnostic criteria of an antral web, including demonstration of echogenic diaphragm-like structure localized at the antral region, gastric dilatation, delay in gastric emptying and a normal pylorus ${ }^{16}$ ). Endoscopy remains a mainstay of diagnosis and the usual finding is the view of a persistent circular elevation of normal mucosa, demonstrating a pinpoint "psudopylorus" which is the evidence of the difficulty of the food to pass up to the duodenum ${ }^{4}$. The first endoscopic description of a gastric antral web was made by Sokol et al. ${ }^{17}$ in 1965 and they stated a very important observation which was that the pinpoint opening of the antral web did not change with gastric peristalsis. Pederson et al state that, generally, normal gastric peristalsis is noted on fluoroscopy and evidence of actual gastric outlet obstruction is unusual ${ }^{15}$. Another possible description to this abnormality is appearance of a mucosal tunnel, as it was in the present case report. Also, the abnormality was misdiagnosed as a pyloric stenosis even with the advance of 
endoscopic diagnostic procedures. This probably happened for its rarity and the association of peptic ulcers. As a consequence, the pacient remained receiving symptomatic drugs like IBP and proper treatment was delayed. The retardation of surgery is actually very common and the majority of cases had complaints for several years before the abnormality could be diagnosed ${ }^{2,3,5,15}$.

Differential diagnosis of antral web includes few possibilities. Redundancy of the gastric mucosa with or without mucosal prolapse, proeminent rugal folds and hipertrophy of the pyloric mucosa can produce a very alike appearance even during surgery which may lead to diagnostic confusion ${ }^{2,4,9,12,13,17,18}$. These pathologies do not form a complete circle around within the antrum like the antral web and may dilate with air-contrast in barium upper gastrointestinal x-ray ${ }^{3}$. Perigastric adhesions and cystogastrocolic bands also must be considered as differential diagnosis ${ }^{9,19,20}$. In the presence of these adhesions, there is a extrinsic compression and are usually limited to the anterior antral wall. We must add to the list another pathology that hasn't been cited as differential diagnosis. Pyloric stenosis should be considered when gastric outlet obstruction is present and associated with peptic ulcer or surgery for its perforation as it was in the present case report. In barium upper gastrointestinal $\mathrm{x}$-ray, antropyloric stenosis may also present signs of gastric stasis and deformation with diminished diameter of the region. What differs the two pathologies is the abnormal mobility of the pylorus and the absence of "double-bulb effect" 21 . This last effect is described only in cases of antral diaphragm.

Sames, when first described this entity in adults, thought that it was congenital in origin ${ }^{1}$. Most authors ${ }^{5,22}$ favor this hypothesis, for antral webs were found in infants with similarly histology. The stomach possesses a relatively freedom from congenital malformations and pyloric or prepyloric atresias accounts for less than $1 \%$ of all atresias ${ }^{23}$. It may originate from incomplete recanalization of antrum and the foregut anlage during 5-6 $6^{\text {th }}$ week of the embryonic age as a incomplete form of membranous atraseia. However, there are authors that state that the diaphragm is an acquired pathology secondary to the healing of peptic ulcers $^{6,24}$. Approximately one quarter of reported cases have been associated with either gastric or duodenal ulcer disease $e^{2,3,4,5}$. Rhind ${ }^{6}$ proposed an "annular" ulceration with subsequent scarring as the mechanism for the web formation. Only one report cites a case of antral web where the previous upper gastrointestinal x-ray series were normal, then after one year another series showed that the patient developed an ulcer in the antrum and the following series evidenced an irregular antral diaphragm ${ }^{14}$. The case in the present report also corroborates with the acquired theory, for the patient had in his surgical history a laparotomy for peptic ulcer disease. However, no previous radiologic study or endoscopic of this patient was available to demonstrate the web. Another feature of antral web symptoms on adults is the late onset of them. One explication for this is the loss of natural teeth and subsequent inadequacy of mastication causing mechanical difficulty and traumatic edema of the membrane which would lead to gastric outlet obstruction ${ }^{25}$. It also should be noted that complete antral diaphragm represents a form of gastric atresia is diagnosed within the first few days of life and incomplete atresia or antral web are diagnosed after the fifth decade of life, a pattern similar to congenital annular pancreas ${ }^{13,16,23,26}$.

Regardless of the etiology, histopatholoy of all antral diaphragms is the same. The diaphragm is composed of mucosa with a common submucosa and muscularis mucosae on both surfaces ${ }^{3,4}$. The muscular wall of the stomach, apart from the muscularis mucosae, takes no part of the antral web. Rare reports of mild or chronic inflammatory changes and diaphragm covered with stratified squamous epithelium, not the columnar epithelium of the stomach, were cited $^{9,11}$. The lack of fibrosis both macroscopically and microscopically could be interpreted as another evidence favoring a congenital origin, for if the antral web was secondary to peptic ulcer healing it would be expected inflammatory changes and fibrosis on the biopsy specimen. Thus the incidence of gastric ulceration associated with antral web could be the result of stasisand excessive antral stimulation. The aperture of the web is usually soft and free of fibrosis. Nonetheless, the opening cannot be dilated without tearing ${ }^{18}$.

There are usually no external visible or palpable signs of antral diaphragm ${ }^{5}$. However, there is a report which an ill-defined groove could be seen on the serosal surface of the stomach which marked the place of the web ${ }^{25}$. In the present case, there was no external or palpable sign of the lesion before gastrostomy was performed.

No proposed classification for antral web had a wide acceptance in the literature. Brown and Hertzler classified congenital obstruction in three types ${ }^{27}$. A) Due to single or double diaphragm; B) An area of mucosal atresia; C) Complete segmented aplasia. Kornfield classified the lesions in diaphragm which completely blocked the lumen and two types of absence of the entire wall of the pylorus ${ }^{28}$. Both classifications are not adequate for antral web found in adults. Gerber ${ }^{5}$ proposed a classification based on gross anatomic basis which could classify both lesions in children and adults. IA) Pyloric membrane; IB) Pyloric atresia; IIA) Antral (1 cm or more proximal to pylorus) membrane; IIB) Antral atresia.

The majority of the patients with antral diaphragm required surgical intervention The natural history of antral web is not well determined, but it is reasonable to say that, as most patients are asymptomatic and it is a benign disease, the surgical treatment is preferably reserved to symptomatic cases. Also, if a diaphragm has aperture larger than $1 \mathrm{~cm}$ generally it does not cause obstruction and may not require surgical treatment ${ }^{3}$. Apparently, all types of surgical intervention works, as long as a functional outlet 
is restored. Pyloroplasty in combination or not with web incision, partial gastrectomy, radial incisions, gastroenterostomy, excision of diaphragm, gastroduodenostomy and gastroplasty were interventions cited in the literature for treatment of antral $\mathrm{web}^{3,5,15}$. Of these, gastroenterostomy had the poorest results and partial gastrectomy is unnecessary to treat such pathology $y^{5}$. In the present case, excision of the antral web was performed with excellent result after 6 months follow-up. The patient is asymptomatic at the moment. Endoscopic treatment through incision of the antral web have been reported with good results ${ }^{10,29}$. Although it sounds very reasonable that endoscopy may treat such disease as effectively as surgery, for many types of intervention have similar results, more cases must be reported for the endoscopic treatment to be considered an option as effective as the surgical excision of the diaphragm.

\section{REFERENCES}

1. Sames CP. Case of partial atresia of pyloric antrum due to mucosal diaphragm of doubtful origin. Brit J Surg. 1949;37:244-6.

2. Hait G, Esselstyn CB Jr, Rankin GB. Prepyloric mucosal diaphragm (antral web): report of case and review of literature. Arch Surg. 1972;105:486-90. doi:10.1001/ archsurg.1972.04180090089021.

3. Ghahremani GG. Nonobstructive mucosal diaphragms or rings of the gastric antrum in adults. Am J Roentgenol. 1974;121(2):236-47. doi: 10.2214/ajr.121.2.236

4. Cho KJ. Gastric antral diaphragm. Gastroint Radiol. 1976:3740. Available from: http://link.springer.com/article/10.1007\% 2FBF02256340\#page-1.

5. Gerber BC. Prepyloric diaphragm, an unusual abnormality: a case report. Arch Surg. 1975;90(4):472-80. doi:10.1001/ archsurg.1965.01320100016004.

6. Rhind JA. Mucosal stenosis of the pylorus. Br J Surg. 1959;46:534-40. doi: 10.1002/bjs. 18004619927

7. Clements JS, Jinkins JR, Torres WE, Thomas BM, Thomas J, Elmer RA, Weens HS. Antral mucosal diaphragms in adults. Am J Roentgenol. 1979;133:1105-11. Available from: http:// www.ajronline.org/doi/pdf/10.2214/ajr.133.6.1105.

8. Conway N. Pyloric antral mucosal diaphragm. BMJ. 1965;I:970-1. Available from: http://www.ncbi.nlm.nih.gov/ pmc/articles/PMC2165650/pdf/brmedj02389-0048b.pdf.

9. Felson B, Berkmen YM, Hoyumpa AM. Gastric mucosal diaphragm. Radiology. 1969;92:513-7. doi: http://dx.doi. org/10.1148/92.3.513

10. Al-Kawas FH. Endoscopic laser treatment of an obstructing antral web. Gastrointest Endosc. 1988;34(4):349-51. doi:10.1016/S0016-5107(88)71374-7.

11. Liechti RE, Mikkelsen WP, Synder WH. Prepyloric stenosis

\section{CONCLUSION}

Antral web is a rare disease that causes gastric outlet obstruction in adults. It presents late onset of clinical manifestations and explanation for this is unknown. Also, there is no consensus of etiology in the literature whether antral web is congenital or acquired when diagnosed in adults. This disease is infrequently reported in adults and it is often misdiagnosed. Diagnosis is difficult even in the during surgery. Endoscopy remains a mainstay of diagnosis but barium upper gastrointestinal $\mathrm{x}$-ray series is also a valuable exam. Surgery can cure patient's symptoms and all types of surgical intervention works, as long as a functional outlet is restored. An illustrative case report in which the antral diaphragm was misdiagnosed for a pylorus stenosis after perforated peptic ulcer surgery was described to call attention of the medical community on this pathology as a possible cause of gastric outlet obstruction.

caused by congenital squamous epithelial diaphragm-resultant infantilism. Surgery. 1963;53(5):670-3.

12. Ferguson IA. Prolapse of the gastric mucosa: report of six cases. Ann Surg. 1948;127(5):879. Available from: http:// www.ncbi.nlm.nih.gov/pmc/articles/PMC1513854/pdf/ annsurg01362-0115.pdf.

13. Slim MS, Bitar I JG, Idriss H. Hypertrophy of the pyloric mucosa: A rare cause of congenital pyloric obstruction. Am J Dis Child. 1964;107(6):636-9. doi: 10.1001/ archpedi.1964.02080060638015.

14. Huggins MJ, Friedman AC, Lichtenstein JE, Bova JG. Adult acquired antral web. Dig Dis Sci. 1982;27:80-6. doi: 10.1007/ BF01308125.

15. Pederson WC, Sirinek KR, Schwesinger WH, Levine BA. Gastric outlet obstruction secondary to antral mucosal diaphragm. Dig Dis Sci. 1984;29:86-90. doi: 10.1007/ BF01296868.

16. Chew AL, Friedwald JP. Donovan C. Diagnosis of congenital antral web by ultrasound. Pediatr Radiol. 1992;22:342-3. doi: 10.1007/BF02016251.

17. Sokol EM, Shorofsky MA, Werther JL. Mucosal diaphragm of the gastric antrum. Gastrointest Endosc. 1965;12:20-8.

18. Parrish RA, Kanavage CB, Wells JA, Moretz WH. Congenital antral membrane. Surg Gynecol Obstetr. 1968;127(5):9991004.

19. Jenkinson EL, Hamernik FJ. Roentgenologic deformities of the pyloric portion of the stomach with absence of surgical and pathological findings 1. Radiology. 1948;51(6):798-805. doi: http://dx.doi.org/10.1148/51.6.798

20. Samuel E. The cystogastrocolic band: radiological considerations. Brit J Radiol. 1952;25(289):19-21. doi: http:// dx.doi.org/10.1259/0007-1285-25-289-19. 
21. Kreel L, Harold E. Pyloric stenosis in adults: a clinical and radiological study of 100 consecutive patients. Gut. 1965;6(3):253-61. Available from: http://www.ncbi.nlm.nih. gov/pmc/articles/PMC1552275/pdf/gut00723-0059.pdf.

22. Tiao M-M, et al. Antral web associated with distal antral hypertrophy and prepyloric stenosis mimicking hypertrophic pyloric stenosis. World J Gastroenterol. 2005;11(4):609-11. doi: 10.3748/wjg.v11.i4.609.

23. Dineen JP, Redo SF. Pyloric obstruction due to mucosal diaphragm. Surgery. 1963;53:674.

24. Gross KE, Durham MW. Pyloric antrum mucosal diaphragm: report of case. Radiology. 1953;61:368-71.

25. James CP. Case of partial atresia of pyloric antrum due to mucosal diaphragm of doubtful origin. Brit J Surg. 1949;37:244-6.

26. Munro AI. Prepyloric mucosal diaphragm. Brit J Surg. 1965;50(227):981-82.

27. Brown RP, Hertzler JH. Congenital prepyloric gastric atresia: a report of two cases. AMA J Dis Children. 1959;97(6):85762.

28. Kornfield HJ. Pyloric atresia and its repair. Surgery. 1962;51:569.

29. Berr F, Rienmueller R, Sauerbruch T. Successful endoscopic transection of a partially obstructing antral diaphragm. Gastroenterology. 1985;89:1147-51. 